\title{
Limnogeology: Ancient and modern tales of an evolving Earth
}

\author{
Lluís Cabrera a , Elisabeth H. Gierlowski Kordesch ${ }^{\mathrm{b}}$, Ana M. Alonso-Zarza ${ }^{\mathrm{c}, *}$, Concha Arenas Abad ${ }^{\mathrm{d}}$ \\ a Geomodels, Dept. Estratigrafia, Paleontologia i Geociències Marines, Universitat de Barcelona, Facultat de Geologia, Campus de Pedralbes, 08028 Barcelona, Spain \\ b Department of Geological Sciences, Ohio University, Athens, OH 45701-2979, USA \\ c Departamento de Petrología y Geoquímica, Fac. CC. Geológicas, IGE-CSIC, Universidad Complutense de Madrid, 28040 Madrid, Spain \\ d Departamento de Ciencias de la Tierra, Universidad de Zaragoza, 50009 Zaragoza, Spain
}

\section{Introduction}

Between the late seventies and the present day, sedimentology and basin research of lakes in the geologic record expanded from a marginal academic curiosity into a spectacular groundbreaking area of multidisciplinary research. Few earth-science disciplines have experienced such great progress in methods and principles in the last three decades as the field of limnogeology. Economic interest in ancient lacustrine basins initially drove research, recognizing lake environments as suppliers of natural resources ranging from evaporitic salts and brines (e.g. lithium), raw materials (i.e. limestones, tufas, clays, and diatomites) and fossil energy (oil, gas, and coals). With this focus, the collection of highresolution, high-quality depositional records of ancient and recent lacustrine systems opened an epoch of continuous expansion of research and improved understanding of these records. Consequently, recognition of the importance of lacustrine deposits as archives of past global changes on continents, which are complementary to marine records, has been growing. Research on lacustrine systems in a wide array of tectonic and climatic settings has been challenged by the variety and intensity of the obvious, and yet subtle, interplay between internal and external driving forces, so well captured by the sensitive lacustrine sedimentary records.

It has been 15 years since the completion of the International Geological Correlation Program Projects on lake sediments (Projects 219 and 324) when earth scientists involved in the study of ancient and recent lacustrine records first began to organize themselves and recognize potential research avenues. The resultant development of an international cooperative entity that involved researchers from more than thirty countries catalyzed the expansion of interest in lacustrine sequences and their resources across the world. This entity is the International Association of Limnogeology (IAL) that promotes the exchange of research ideas at its international congresses. Copenhagen (Denmark, 1995) witnessed the first International Limnogeology Congress (ILIC 1 ) that was followed by others in Brest (ILIC 2: France, 1999), Tucson, Arizona (ILIC 3: USA, 2003), and most recently in Barcelona (ILIC 4: Spain, 2007).

\section{The 4th International Limnogeology Congress of Barcelona}

The 4th International Limnogeology Congress (i.e. the quadrennial congress of the International Association of Limnogeology) was held in Barcelona in the summer of 2007 (July 11th-14th). The Local Organizing Committee chaired by Lluís Cabrera processed 359 submitted abstracts of representatives from 35 countries worldwide. The representation from Europe and America was dominant, but contributions from Asia and Africa were also significant. Four full days of plenary sessions, presentations, and posters were planned.

In addition, five pre- and post-meeting field trips that covered a wide range of ancient to recent continental records were arranged during this congress. They included several trips to the Pyrenees and its southern foreland area, especially the Cenozoic Ebro basin. The Late Eocene lacustrine and fluvial record in the eastern Ebro basin was the subject of the trip led by A. Sáez and co-workers. The Late Oligocene lacustrine archives in the SE Ebro basin and the Neogene succession in the central Ebro basin were visited in the field trips led by P. Arbués and co-workers and by C. Arenas and coworkers, respectively. The Carboniferous-Permian lakes of the Pyrenees and the Quaternary lakes of the Ebro basin were the subject of the trip led by B. Valero Garcés and co-workers. The trip to the Miocene lake sequences of La Cerdanya basin, proposed by $\mathrm{C}$. Martín Closas and Xavier Delclos, completed the overview of the Tertiary lacustrine record in NE Spain offered by the congress. The guidebook covering the geology of these trips in northeast Spain was published by the Geological Society of Spain (edited by C. Arenas, A.M. Alonso Zarza, and F. Colombo) as volume three of its "Geo-Guías" series.

The meeting itself comprised days that started with a morning plenary session followed by oral presentations, including key notes talks, and posters focused on a wide range of lake deposits from very ancient Precambrian deposits in North America to recent lakes in Eurasia, America, and Africa. The breadth of research on lake sediments exposed in this congress was impressive, from pioneering research on the inorganic chemistry of sediments to reconstructions of paleoenvironmental evolution from lacustrine records.

Talks and posters covered such topics as the use of molecular biomarkers for determining changes in the structure of lacustrine algal communities through time, the use of non-destructive XRF analysis 
on whole cores, the use of lake cores for determining human modification of local basins and regional economies, exploration of lake basins on Titan (Jupiter's moon), and microbiologic aspects of mineral formation. In addition, new and improved isotopic and dating techniques were discussed in many papers. One of the main issues in the science of limnogeology since its inception has been the accurate dating of cores using multiple techniques; a number of sessions at this conference were devoted to this still hot topic. However, many of the techniques discussed either need other traditional techniques for verification or are only applicable to specific, short time periods, or restricted localities. Overall, a look at the range of topics in the abstract volume shows the significant technological progress in limnogeologic investigations since the first ILIC in 1995.

A highlight of the meeting was the presentation of the Bradley medal of the International Association of Limnogeology to a prestigious limnogeologist who also has served the community: Professor Michael R. Talbot of the University of Bergen (Norway). For many years Mike Talbot has been a tireless promoter of lake research and has mentored many students from Norway and abroad. He also launched the first IGCP lake project (IGCP-219, Comparative Lacustrine Sedimentology in Space and Time) along with Kerry Kelts who was the catalyst for organizing lake scientists globally and the seed that gave rise to the International Association of Limnogeology.

Tragedy struck the conference early in the morning of the last day of the meeting, before the morning plenary session, with the collapse and death of Tim Brewer from the Geology Department of the University of Leicester. We would like to honour our colleague, because with his death the limnogeology community lost a good colleague and a friend. He will be truly missed.

The thirteen papers assembled in this thematic issue of Sedimentary Geology are part of the research presented at ILIC 4. The objectives of this issue were mainly to provide new data and views on lacustrine depositional processes and system evolution in some recent and ancient case studies. The geographic distribution and time range of the contributions are wide, and includes southwestern Europe (with representation from the Mesozoic, Tertiary, Neogene-Quaternary, and Recent records of Spain and Italy), Asia (Miocene and Quaternary from southern China-Tibet), Africa (Quaternary of Kenya), South America (Triassic of Argentina), and Oceania (Miocene of New Zealand).

Irrespective of their geographic location, the contributions can be grouped by their varied scope into four major thematic groups: (1) Recent and ancient lacustrine records studied from a sedimentologic perspective, (2) tectonic settings of lacustrine systems, (3) paleoclimatic records in lacustrine deposits, and (2) paleobiologic records and microbial mineral precipitation in lakes.

The first group of five papers provides an overall view in ongoing research projects on ancient to recent lacustrine deposition and its modelling. The paper by Soler et al., (2009) focuses on the important role played by hydrothermal turbid plumes in the sedimentation developed in a Holocene karstic lake (Banyoles Lake, NE Spain). The sedimentation rates and distribution of sediment in the water column are exclusively controlled by basin morphology and the intensity of plumes sourced by groundwater. The intensity of the subterraneous groundwater recharge through the lacustrine bottom is linked to precipitation in the recharge zones. The paper by Gratacós et al., (2009) also deals with the analysis of the distribution of sediments in a lacustrine water column, in this case an artificial lake (Camarasa, NE Spain) in an elongated valley. This analysis is based on a comparison of observed data with output of a forward modelling program (SIMSAFADIM-CLASTIC program) that simulates transport and deposition of clastic sediments. The following two papers present detailed sedimentologic analyses of two different basins in Asia which contain fluvio-lacustrine deposits. The paper by Kempf et al., (2009) deals with sedimentologic, petrographic, and paleoecologic data from a thick section of late Neogene (ca. 9-7 to
$1 \mathrm{Ma}$ ) fluvio-lacustrine deposits in the high-elevation Zhada Basin of SW Tibet. Based on detailed analyses of five sedimentary units, climate is considered to cause the transition from lacustrine to alluvial sedimentation in the upper part of the section, so the change in the sedimentary environments reflects the onset of northern hemisphere glaciation and winter monsoon strengthening at $\sim 2.6 \mathrm{Ma}$. Alonso-Zarza et al., (2009) present a sedimentologic study of the upper Neogene deposits of the Tianshui Basin (China). The paper provides data which indicate that these deposits accumulated in a complex alluvial-lacustrine environment under a strong climatic control. This paper is somewhat controversial as this sequence of sediments was previously interpreted as loess. Martín-Serrano et al., (2009) contribute a paper describing the morphotectonic setting of maar lakes in central Spain (Campo de Calatrava Volcanic Field) as well as the sedimentologic record in two selected ancient lakes in the area. This paper provides preliminary information on a volcanic region in SW Europe that deserves attention for the potential of its lacustrine records to unravel climatic change and tectonic evolution of the area.

Sedimentary facies models and tectono-sedimentary analysis are the major scopes of the second group of papers with three contributions from the Mediterranean region.

The paper by Meléndez et al., (2009) presents a sedimentologic analysis of Early Cretaceous alluvial and lacustrine deposits linked to early rifting in the Central Iberian Chain (Spain). The distribution of facies associations through space and time indicates a general evolution from alluvial to isolated ponds, then to a low-energy shallow lake and finally to an extensive high-energy lake. This evolution is shown to be related to changes in the subsidence pattern determined by the transition from the initial rift to the rift climax stage. The study concludes that, paralleling this change, the basin evolved from an overfilled to a balanced-fill lake basin through time. The contribution is an excellent example of a combination of sedimentary and tectonic analysis as a way to understand the complete lacustrine basin evolution. Onofrio et al., (2009) provide a detailed tectonic and sedimentologic study on Quaternary lacustrine sedimentation of the San Lorenzo Succession in the southern Apennines in Italy. The paper uses the relation between tectonics and sedimentation to illustrate how the movement of the different tectonic structures controlled the development and morphology of the fluvial and lacustrine basins during relatively recent times. Finally, the tectono-sedimentary analysis of lacustrine facies in one of the most active tectonic areas in southeast Spain (intraplate Albacete province) allows Rodríguez-Pascua et al., (2009) to reconstruct the Quaternary paleoseismic history and tectonic slipping rate of the region. This contribution shows that different lacustrine sedimentary phases reflect episodic activity of the nearby faults, as defined by different values of the slip rate ranging between 0.05 and $0.09 \mathrm{~mm} / \mathrm{year}$. In addition, empirical relationships for the fault displacement and the surface-length rupture allow the estimation of moderate-sized paleoearthquakes (M6) associated with fault activity in this intraplate zone of the Iberian plate. This study thus highlights the role of lacustrine deposits as archives of earthquake activity.

A third group consisting of two papers provides an overview of ongoing research involving paleoclimatic records. Lindqvist and Lee (2009) analyze the high-frequency paleoclimate signals from an Early Miocene varved, lacustrine diatomite succession in the Foulden Maar. The high quality and good preservation of these deposits and their location in southern New Zealand enable the authors to make some interesting suggestions about Early Miocene climatic changes in this Pacific region. Gauthier and Muñoz (2009) focus on the study of a laminated lacustrine section from the Pliocene Villarroya Lake in northern Spain. The palynologic and sedimentologic analyses allowed the authors to differentiate eight pollen cycles related to short-term climatic fluctuations due to seasonality in precipitation, not directly with temperature oscillations. These fluctuations could be correlated with the NAO/ENSO-like and sunspot-like cycles. Thus, the paper 
provides a good case study of how pollen analyses contribute to a better understanding of high-frequency climatic changes in lacustrine deposits.

This issue concludes with three papers focused on the paleobiologic aspects of lake deposits. Owen et al., (2009) describe wetland sedimentation, including the associated diatoms, which developed in the Pleistocene Olorgesailie Basin (southern Kenya, Great Rift Valley). The integrated sedimentologic and paleobiologic (including paleoichnologic) approach outlined in this paper enable the authors to better constrain interpretations of depositional conditions under fluctuating lake levels. The role of microbial activity in lacustrine sedimentation is presented by Sanz-Montero et al., (2009) through petrographic, isotopic, and compositional data of several Miocene successions in two closed basins in central Spain. The paper provides an ancient analogue for biologically-mediated celestite and barite formation in dolomite-precipitating microbial mats. Sulfide oxidation by microbes is thought to mediate the transformation of reduced sulfur to oxidized forms as source of sulfate for barite and celestite, which nucleated on organic substances. Sulfide oxidation and reduction are established as processes that also favor concomitant formation of dolomite. The paper therefore reinforces the idea of biologic formation of dolomite in saline lakes. The taphonomic analysis carried out by Mancuso (2009) in two Triassic lacustrine basins in Argentina allows reconstruction of two different sedimentary environmental contexts mostly based on paleoflora. Plant fossil assemblages along with associated palynoflora are well preserved as possible original communities for this part of western Gondwana. Large, deep lake settings preserve more extensive flora with evergreen forest elements, whereas small shallow lake settings only preserve flora associated with lake margins. The paper reinforces the importance of flora in paleoenvironmental reconstructions.

\section{Concluding remarks}

The contributions to this Sedimentary Geology issue provide a heterogeneous but rich assembly of single case studies embracing several types of records, depositional processes, and basin types. Further, they increase our knowledge of lacustrine successions in some previously poorly known regions and fit new pieces into the lacustrine record puzzle. We still have far to go in assembling a full universal picture on lakes and their formation and evolution, but any new piece takes us closer to the IAL final goal of integration and understanding of lake environments through time and space.

The mainstream in lacustrine research is today mainly focused on the study of Modern to Recent records to derive high-resolution, Holocene paleoenvironmental evolution in lakes across the world. This research supports the deep concern of our societies with global climatic change and its environmental effects on our food supply and living conditions. The contributions of the studies dealing with the sedimentology and diagenesis of ancient lake deposits as well as the evolution of lacustrine basin fills will contribute knowledge to guarantee and secure a continuous supply of natural resources. The early discoveries in the seventies of major hydrocarbon reserves related to lacustrine facies, including the Cretaceous pre-salt sequences of offshore of Brazil and western Africa, were a major catalyst for the evolution of important concepts and the development of significant studies on lacustrine sequences. The need to increase the capacity of hydrocarbon recovery from these sequences and the new oil findings related to these ancient lacustrine sequences have recently renewed and reinvigorated research, opening a new era for improving ideas and developing techniques in Limnogeology.

We would like to encourage researchers of lacustrine records, especially from the world's regions from which there have been fewer participants at the previous congresses, to contribute to future
IAL congresses. Moreover, international and local agencies from private and public sectors should support the participation of researchers from these geographic regions. Their support is crucial in promoting international communication that will be reflected not only in the advancement of knowledge but also in the improvement in global cooperation. An excellent opportunity occurs in 2011 with the 5th International Limnogeology Congress (ILIC 5) that will be held in Germany in the summer of 2011. Dr. Antje Schwalb (Braunschweig) heads the organizing committee. We all look forward to another meeting full of lake research topics and discussion on lakes and the information stored in their sedimentary archives.

\section{Acknowledgments}

The ILIC 4 received the support of several agencies and institutions that are acknowledged for their contribution to the success of the meeting: Ministerio de Educación y Ciencia, Instituto Geológico y Minero de España, Generalitat de Catalunya and its Institut Geològic de Catalunya, Universitat de Barcelona, CosmoCaixa (Fundació "La Caixa"), Consejo Superior de Investigaciones Científicas (CSIC), Sociedad Geológica de España, International Association of Sedimentologists (IAS), Agència Catalana de l'Aigua, Institut d'Estudis Catalans (IEC), ExxonMobil, Repsol, and Aigües del Ter Llobregat. We also wish to acknowledge the support from our Departments and Schools: Faculty of Geology of Barcelona and its Department of Stratigraphy, Paleontology and Geomarine Sciences; Petrology and Geochemistry Department of the Faculty of Geology of Madrid (Complutense University), Department of Earth Sciencies of the University of Zaragoza and Department of Geological Sciences, Ohio University. All the papers in this Sedimentary Geology issue were critically refereed by two or three independent and qualified peers, revised by the authors, and edited by the guest editors of the special issue and the responsible journal editor before being accepted for publication. On behalf of the authors and ourselves we deeply acknowledge the kind cooperation received from journal editor G.J. Weltje and the followings reviewers: I. Armenteros, M.E. Arribas, S. Bao, A. Bertini, G. Büchel, G. P. Cavinato, A.S. Cohen, N. Combourieu-Nebout, B. Curry, S. Douglas, Ch. Dupraz, R. K. Edgar, A. Folkard, D. Ferguson, F. Fluteau, R.A. Gastaldo, K. Harberyan, M. Hinderer, A.D. Jones, H.F. Lamb, E. Masana, A. Meléndez, M.N. Meléndez, T. Mulder, A. Navas, K. Németh, V. Pascucci, K. Reicherter, L. Sábato, A. Sáez, M.E. Sanz, A.R. Soria, A. Strasser, J. Szulc, L.H. Tanner, J.C. Tipper, M.E. Tucker, and A. Yildiz.

\section{References}

Alonso-Zarza, A.M., Zhao, Z., Song, C.H., Li, J.J., Zhang, J., Martín-Pérez, A., Martín-García, R., Wang, X.X., Zhang, Y., Zhang, M.H., 2009. Mudflat/distal fan and shallow lake sedimentation (upper Vallesian-Turolian) in the Tianshui Basin, Central China: Evidence against the late Miocene eolian loess. Sedimentary Geology 222, 42-51.

Gauthier, Agnès, Muñoz, Arsenio, 2009. Seasonal sedimentation in the Pliocene Villarroya Lake (N Spain) inferred from pollen analysis. Sedimentary Geology 222, 111-123.

Gratacós, O., Bitzer, K., Casamor, J.L., Cabrera, L., Calafat, A., Canals, M., Roca, E., 2009. Simulating transport and deposition of clastic sediments in an elongate basin using the SIMSAFADIM-CLASTIC program: The Camarasa artificial lake case study (NE Spain). Sedimentary Geology 222, 16-26.

Kempf, Oliver, Blisniuk, Peter M., Wang, Shifeng, Fang, Xiaomin, Wrozyna, Claudia, Schwalb, Antje, 2009. Sedimentology, sedimentary petrology, and paleoecology of the monsoon-driven, fluvio-lacustrine Zhada Basin, SW-Tibet. Sedimentary Geology 222, 27-41.

Lindqvist, Jon K., Lee, Daphne E., 2009. High-frequency paleoclimate signals from Foulden Maar, Waipiata Volcanic Field, southern New Zealand: An Early Miocene varved lacustrine diatomite deposit. Sedimentary Geology 222, 98-110.

Mancuso, Adriana Cecilia, 2009. Taphonomic analysis in lacustrine environments: Two different contexts for Triassic lake paleofloras from Western Gondwan (Argentina). Sedimentary Geology 222, 149-159.

Martín-Serrano, A., Vegas, J., García-Cortés, A., Galán, L., Gallardo-Millán, J.L., MartínAlfageme, S., Rubio, F.M., Ibarra, P.I., Granda, A., Pérez-González, A., García-Lobón, J.L 2009. Morphotectonic setting of maar lakes in the Campo de Calatrava Volcanic Field (Central Spain, SW Europe). Sedimentary Geology 222, 52-63.

Meléndez, Nieves, Liesa, Carlos L., Soria, Ana R., Meléndez, Alfonso, 2009. Lacustrine system evolution during early rifting: El Castellar Formation (Galve sub-basin, Central Iberian Chain). Sedimentary Geology 222, 64-77. 
Onofrio, Vincenzo, Tropeano, Marcello, Festa, Vincenzo, Moretti, Massimo, Sabato, Luisa, 2009. Quaternary transpression and lacustrine sedimentation in the San Lorenzo area (Sant'Arcangelo Basin, Italy). Sedimentary Geology 222, 78-88.

Owen, R. Bernhart, Renaut, Robin W., Scott, Jennifer J., Potts, Richard, Behrensmeyer, Anna K., 2009. Wetland sedimentation and associated diatoms in the Pleistocene Olorgesailie Basin, southern Kenya Rift Valley. Sedimentary Geology 222, 124-137.

Rodríguez-Pascua, M.A., Bischoff, J., Garduño-Monroy, V.H., Pérez-López, R., Giner-Robles, J.L., Israde-Alcántara, I., Calvo, J.P., Williams, R.W., 2009. Estimation of the tectonic slip-rate from Quaternary lacustrine facies within the intraplate Albacete province (SE of Spain). Sedimentary Geology 222, 89-97.
Sanz-Montero, M. Esther, Rodríguez-Aranda, J. Pablo, García del Cura, M. Angeles, 2009 Bioinduced precipitation of barite and celestite in dolomite microbialites. Examples from Miocene lacustrine sequences in the Madrid and Duero Basins, Spain. Sedimentary Geology 222, 138-148.

Soler, Marianna, Serra, Teresa, Casamitjana, Xavier, Colomer, Jordi, 2009. High sedimentation rates in a karstic lake associated with hydrothermal turbid plumes (Lake Banyoles, Catalonia, NE Spain). Sedimentary Geology 222, 5-15. 